\title{
A Bibulous Couch ([Verg.] Copa 5-6)?
}

\section{Citation}

Thomas, Richard F. 1991. A bibulous couch ([Verg.] Copa 5-6)? Classical Philology 86(1): 41-43.

\section{Published Version}

doi:10.1086/367230

\section{Permanent link}

http://nrs.harvard.edu/urn-3:HUL.InstRepos:3775755

\section{Terms of Use}

This article was downloaded from Harvard University's DASH repository, and is made available under the terms and conditions applicable to Other Posted Material, as set forth at http:// nrs.harvard.edu/urn-3:HUL.InstRepos:dash.current.terms-of-use\#LAA

\section{Share Your Story}

The Harvard community has made this article openly available.

Please share how this access benefits you. Submit a story.

\section{Accessibility}


to have verged on the agnostic at times. ${ }^{26}$ The alternative interpretation - whatever Ovid himself believed - would be to view these passages as essentially a rhetorical exercise aimed at a public, elements of which were themselves convinced of the efficacy of Divus Augustus. If that is the case, then the poet's reference to the deceased emperor can be seen as a strategy by which Ovid played upon a popular belief, current in Rome, ${ }^{27}$ in the hope that it would help to save him from miserable exile.

DUNCAN FishWICK University of Alberta

26. Cf. Ars am. 1. 637-38 "expedit esse deos et, ut expedit, esse putemus; / dentur in antiquos tura merumque focos."

27. The outlook that seems to lie behind the passages cited above differs radically from the rationalist view of deification as simply a posthumous reward for meritorious services rendered during life; cf. Nock, "Deification," p. 121, with n. 47 (= Essays, p. 844, with n. 47), citing Min. Fel. Oct. 21.9 "qui consecrantur non ad fidem numinis sed ad honorem emeritae potestatis." But clearly in the vast Roman Empire one should expect differing perceptions of the emperor's deification and what it implied. Not everyone was a rationalist theologian.

\title{
A BIBULOUS COUCH ([VERG.] COPA 5-6)?
}

\author{
quid iuvat aestivo defessum pulvere abesse \\ quam potius bibulo decubuisse toro? \\ 5 abesse ] abisse Ilgen: 6 bibulo ] vivo Schenkl
}

So the poet - or the poet in the guise of the innkeeper (caupo), or the copa herself, or possibly even the animated taberna-begins an enumeration of the tavern's attractions. ${ }^{1}$ It is not just the punctuation of this couplet that "requires more consideration than it has commonly received." ${ }^{2}$ The greater problem lies in the words bibulo . . toro; as Goodyear asked: "What is this bibulus torus on which the wayfarer is invited to recline?" He reviews the current options. The couch might be splashed with wine ${ }^{3}$ or we might understand a grass couch al fresco,

I wish to thank my colleague, R. J. Tarrant, whose forthcoming article ("Nights at the Copa: Observations on Language and Date," HSCP 94 [1991]) led me to examine the problems of this couplet.

1. For the arguments for and against these various possibilities, see F. R. D. Goodyear, "The Copa: A Text and Commentary," BICS 24 (1977): 118-19. I incline to Wilamowitz' view, although the issue is not as straightforward or easy as he implies: "Nicht die leiseste Andeutung führt davon ab, dass der Dichter redet" (Hellenistische Dichtung, vol. 2 [Berlin, 1924], p. 311). The claim of Goodyear and others that the poet cannot, propria persona, address a passing traveler (none is actually named, and so the issue is kept rather vague) is perhaps excessively rationalistic. This issue, like that of the punctuation of the couplet (see below, n. 2), does not affect the central contribution of the present note.

2. Goodyear, "The Copa," p. 122. I have opted to follow Kenney's punctuation (in the OCT), taking quam potius as potius quam, with full regard for the scarcity of parallels. The alternative, in which quam = quanto and line 6 becomes an exclamation in response to the question posed in line 5 , seems to me to mar the parallelism of the couplet.

3. Supported by Ov. Ars am. 1. 233 "vinaque cum bibulas sparsere Cupidinis alas"-a "remote analogy" (Goodyear, ibid.). 
splashed by, and therefore bibulous of, a nearby stream, perhaps the one mentioned in line $12 .{ }^{4}$ But the couplet is an advertisement, and both of these options fail for that reason: as Goodyear remarks on the first, "Dirty furniture is a poor recommendation"; as for the second, though rivers are features of the locus amoenus - chiefly for the coolness they provide, or for their pleasant sound (the context of line 12, "est crepitans rauco murmure rivus aquae")-the prospect of lying on their damp, mossy banks will not have had great appeal. ${ }^{5}$ Scaliger realized this, and suggested for bibulo ...toro a couch on which much drinking be done. This alone, so far, gives tolerable sense, and drinking-mentioned at lines $7,11,20,29-30$, and 37-should presumably receive such an early mention in a poem about a tavern; but "the transference of ideas involved is bold and may defy parallel altogether." 6

The solution is simple: for bibulo read bibulum, "What pleasure in being outside worn out with summer's heat, rather than lying at the couch drinking?"7 Bibulum ("drinking") responds to aestivo defessum pulvere ("thirsty"), and the two accusatives are then subjects of the respective infinitives, abesse ("be outside") and decubuisse toro ("lie at the couch," i.e., "be inside"), ${ }^{8}$ which are likewise in responsion. The couplet's elegant chiasmus, with its blend of balance and imbalance, is evident:

$\begin{array}{lll} & \text { ACC. SUBJECT PHRASE/ } & \text { INFINITIVE/ } \\ \text { ACC. SUBJECT } & \text { INFINITIVE PHRASE } \\ \text { NEG. } & \text { aestivo defessum pulvere } & \text { abesse } \\ \text { POS. } & \text { bibulum } & \text { decubuisse toro }\end{array}$

The corruption is an easy one. J. Willis has shown with what frequency this alteration occurs through scribal desire to create rhyme both in the hexameter (from penthemimeral caesura to line-end) and, as here, in the pentameter (from medial caesura to line-end) - since such rhyme occurs so frequently in elegiacs, including in this poem. ${ }^{9}$ Indeed, within the Copa itself, there may be a second instance of precisely this type of corruption; ${ }^{10}$ and a similar psychological expecta-

4. This option, put forward by C. D. Ilgen (Animadversiones Philologicae et Criticae in Carmen Virgilianum quod Copa Inscribitur [Schulpforta, 1820], pp. 28-29), "perhaps . . . puts more weight on bibulo than the word can bear" (Goodyear, "The Copa," p. 122); it bred Schenkl's emendation vivo.

5. Anyway, as Goodyear noted, if 6 merely means "there is a river nearby," then 12 becomes superfluous.

6. So Goodyear, “The Copa," p. 122. The parallel from Val. Flacc. 1. 294-95 (quietis . . toris) seems much less extreme an instance, and different in kind: the effect caused by the couch is ascribed to it as a quality, which is much more natural a transference than that in bibulo . . toro.

7. The adjective is applied to persons rarely, but the pedigree is good: Hor. Epist. 1. 14. 34 bibulum ... Falerni, where bibulum = bibentem, as at Copa 6. Epist. 1. 18.90, with its potores bibuli, gives a second instance; although the line is probably not Horatian, it is Latin. This latter instance shows that bibulus may be applied to persons in a general way, without an objective genitive such as is found at Epist. 1. 14. 34 (Falerni).

8. At least in the sense of being in the shade, under an arbor, vel sim.

9. Latin Textual Criticism (Urbana-Chicago-London, 1972), pp. 102-10; in defending Housman's formosus at Prop. 1. 19.13 (which removes the rhyme formosae ... heroinae), Willis refers to "the taste of the monastic meddler, unhappy without his rhyme"(p. 106). Cf. the rhyme in the hexameters at Copa 3 fumosa . . taberna, 7 calybae... chordae, 9 Maenalio ... antro, 11 cado . . picato, 29 aestivo... vitro, 31 pampinea . . umbra, [possibly] 33 tenerae . . puellae (see below, $n$. 10); in the pentameters at 4 raucos . . calamos, 14 purpurea . . rosa, 16 vimineis . . . calathis, 32 roseo . . . strophio.

10. If at 33 Clausen's formosa interea is correct (or rather, if tenerae at least is corrupt), tenerae... puellae represents another instance of scribal "rhyme creation." Goodyear, "The Copa," p. 127, prefers the obelus, but inclines to Clausen's proposal vs. Courtney's formosa en tenerae. 
tion protected this error once it had taken place, as is evidenced in part by the only conjecture, Schenkl's vivo, which preserves the rhyming adjective-noun combination. Once bibulo is in place, it will not easily be budged from the minds of readers who consciously or otherwise expect patterns of rhyme because rhyme is so basic in their own poetic systems. Bibulo was also presumably protected by the apparent but false parallelism: ${ }^{11}$

aestivo defessum pulvere

bibulo decubuisse toro

As for Ilgen's abisse, it now perhaps seems less "palmary" (so Goodyear), once we see the exact parallelism between "being inside (drinking)" and "being outside (thirsty)." Moreover-and particularly if one sees the speaker as the poet-abisse, with its assumption of discourse and even argumentation with a specific passerby (who is beginning to veer away from the taberna), does not really find justification in the poem. ${ }^{12}$

RICHARD F. THOMAS Harvard University

11. Cf. Goodyear, ibid., p. 122: “As Professor Kenney observes, the phrasing suggests that bibulo is opposed in sense to aestiuo."

12. Goodyear, ibid., pp. 122, 132, cites as parallels Anth. Pal. 16. 227, 228, which invite wayfarers to rest by shady fountains. Though these are surely part of the background of the Copa, they are only vaguely a "source"; and significantly, each of these, unlike our poem, places the wayfarer prominently in

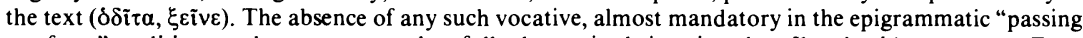
wayfarer" tradition, perhaps suggests a less fully dramatized situation than Ilgen's abisse assumes. Even with abisse, of course, bibulum still stands.

\section{THE YEARS 394 AND 395 IN THE EPITOMA CHRONICON: PROSPER, AUGUSTINE, AND CLAUDIAN}

The literary sources used by Prosper of Aquitaine in continuing Jerome's chronicon for the period 379-455 have been notoriously elusive. ${ }^{1}$ Since Oswald Holder-Egger's study of the Epitoma chronicon (1876), investigators have become ever more reluctant to isolate and identify specific sources behind Prosper's information. At this time only the De haeresibus of Augustine remains unchallenged. ${ }^{2}$ Yet a previously unrecognized similarity between Prosper's notices for the

1. The Epitoma chronicon is cited from the edition of T. Mommsen, Chronica Minora, vol. 1 (MGH:AA, 9:341-499). Prosper issued the chronicon in several editions, first in 433 and finally in 455. On the various editions, see Mommsen's introduction, pp. 345-47, with S. Muhlberger, "Prosper's Epitoma chronicon: Was There an Edition of 443?" CP 81 (1986): 240-44. On Prosper, see still L. Valentin, Saint Prosper d'Aquitaine: Étude sur la littérature latine ecclésiastique au cinquième siècle en Gaule (Paris and Toulouse, 1900). The question of Prosper's sources is particularly crucial for the years between the end of Jerome's Chronicle in 378 and the early 420s, for Prosper, born about 390, would have had to rely on written or oral sources for that period; see Valentin, ibid., p. 416.

2. O. Holder-Egger, "Untersuchungen über einige annalistische Quellen zur Geschichte des fünften und sechsten Jahrhunderts," Neues Archiv 1 (1876): 13-120, 213-368, esp. $15-90$ ("Die Chronik Prospers von Aquitanien," with pp. 80-89 on sources); more cautiously Valentin, Saint Prosper, pp. 418-22, 426-27. See now the recent critical judgment of S. Muhlberger, "Prosper, Hydatius, and the Chronicler of 452: Three Chroniclers and Their Significance for Fifth-Century Historiography" (Ph.D. diss., 